1

\title{
Energetic assessment of air-steam gasification of sewage sludge and of the integration of sewage sludge pyrolysis and air-steam gasification of char.
}

\author{
N. Gil-Lalaguna *, J. L. Sánchez, M. B. Murillo, M. Atienza-Martínez, G. Gea \\ Thermo-chemical Processes Group, Aragón Institute of Engineering Research (I3A), Universidad de \\ Zaragoza, c/ Mariano Esquillor s/n., 50018, Zaragoza, Spain. \\ *Corresponding Author Tel: +34976762224ｅ-mail: noemigil@unizar.es
}

\begin{abstract}
Thermo-chemical treatment of sewage sludge is an interesting option for recovering energy and/or valuable products from this waste. This work presents an energetic assessment of pyrolysis and gasification of sewage sludge, also considering the prior sewage sludge thermal drying and the gasification of the char derived from the pyrolysis stage. Experimental data obtained from pyrolysis of sewage sludge, gasification of sewage sludge and gasification of char (all of these performed in a lab-scale fluidized reactor) were used for the energetic calculations. A theoretical study based on gasification equilibrium data is also included in this work, showing improved gasification efficiencies at equilibrium compared to experimental data. Experimental data showed that the energy contained in the product gases from pyrolysis and char gasification is not enough to cover the high energy consumption for thermal drying of sewage sludge. Additional energy could be obtained from the calorific value of the pyrolysis liquid, but some of its properties must be improved facing towards its use as fuel. On the other hand, the energy contained in the product gas of sewage sludge gasification is enough to cover the energy demand for both the sewage sludge thermal drying and the gasification process itself.
\end{abstract}


Keywords: sewage sludge, char, air-steam gasification, pyrolysis, thermal drying.

\begin{abstract}
Abbreviations
$\Delta \mathrm{H}$ : total enthalpy; $\Delta \mathrm{H}_{\text {cond }}$ : enthalpy of condensation; $\Delta \mathrm{H}_{\mathrm{f}}^{\mathrm{o}}$ : standard enthalpy of formation at $298 \mathrm{~K} ; \Delta \mathrm{H}_{\mathrm{vap}}$ : enthalpy of vaporization; AP: aqueous phase; $\mathrm{Cp}$ : specific heat capacity; daf: dry and ash-free; DSC: differential scanning calorimetry; ER: equivalence ratio; HHV: higher heating value; HOP: heavy organic phase; LHV: lower heating value; LOP: light organic phase; m: mass flow rate; $\eta_{\text {gas }}$ : dry gas yield; Q: heat of reaction; $\mathrm{Q}_{\text {drying: }}$ heat needed for thermal drying; $\mathrm{S} / \mathrm{B}$ : steam to dry and ash-free biomass mass ratio; S/C: steam to carbon molar ratio; SS: anaerobically digested and thermally dried sewage sludge; STP: standard conditions of temperature and pressure; $\mathrm{T}_{\mathrm{b}}$ : boiling point; $\mathrm{T}_{\text {ref: }}$ reference temperature $(298 \mathrm{~K})$.
\end{abstract}

\title{
1. Introduction
}

Sewage sludge is the major by-product of wastewater treatment. The sludge stemming from the wastewater treatment usually appears in the form of a dilute suspension, which typically contains from 0.25 to 12 wt. \% of dry solid matter, depending on the operation and process used [1]. The generated amount of this waste has increased in recent years due to the stricter European legislation concerning urban wastewater treatment [2], which has led to an increase in the number of wastewater treatment plants. As a consequence, sewage sludge management has become an important issue [3].

Sewage sludge has been traditionally used as fertilizer due to its organic matter and nutrient content. However, the presence of various contaminant elements in the sludge such as heavy metals, organic contaminants and pathogenic bacteria limits this practice, which is regulated by European environmental legislation [4]. Landfill disposal and 
incineration are other common ways of sewage sludge management, but they are not exempt from drawbacks [1]. Thus, different energy valorization technologies are currently being developed. Among them, thermo-chemical processes such us gasification and pyrolysis represent interesting options since they could provide energy and/or valuable products from sewage sludge $[5,6]$. A large number of lab-scale studies on sewage sludge pyrolysis for liquid production (fast pyrolysis) can be found in the literature [7-9]. Besides the liquid fraction, a gas stream and a carbonaceous solid byproduct (char) are also obtained in the process. The remaining organic fraction in char gives it a moderate calorific value which could be further exploited through thermochemical processes such as gasification, thus providing a route towards the complete energetic valorization of the biomass [10-12]. In addition to the pyrolysis works, sewage sludge gasification has been studied since mid-1990s [13]. Since then, numerous studies have been performed at laboratory plants [14-17] and the process has even been tried at demonstration and pilot scale [18-20]. Most of these studies used air as a gasification medium, but steam gasification or supercritical water gasification of sewage sludge have also been performed in order to enhance $\mathrm{H}_{2}$ production and improve gas quality $[21,22]$. However, the addition of steam into a gasification process accelerates a series of endothermic reactions that result in a decrease in temperature, making it more difficult to achieve an autothermal process [23, 24]. Therefore, not only technical and operational aspects should be taken into account for the development of a gasification process. Energetic assessment is also a key issue, especially when steam is used as a gasifying agent.

The energy needed for steam gasification can be achieved by the addition of oxygen (or air, since the use of pure oxygen raises the process cost) together with the steam into the gasification medium, which causes the combustion of part of the organic matter and 
the release of energy. The gasification temperature is controlled by the oxygen supply itself in an autothermal gasifier, while the transfer of external heat is required in an allothermal gasifier to maintain a suitable temperature during the process.

Several works reported in the literature describe energetic aspects related to the gasification and pyrolysis of different types of biomass [25-29], but not specifically refer to the use of sewage sludge. Given this background, this paper presents an energetic assessment of two potential treatments for sewage sludge: (i) sewage thermal drying + air-steam gasification of sewage sludge and (ii) sewage sludge thermal drying + pyrolysis of sewage sludge + air-steam gasification of the char derived from the pyrolysis stage. Fig. 1 shows a schematic overview of both treatments. The objective of this study is to determine the overall energy demand of these thermo-chemical processes by considering the individual energy requirement of each stage (drying, pyrolysis and gasification). Experimental data resulting from the pyrolysis and gasification stages were used in the energy balances. Furthermore, theoretical simulations of the gasification stages (performed with the HSC Chemistry® 6.1 software and based on the Gibbs energy minimization method) were also conducted in order to evaluate the thermodynamic restrictions of the process under different scenarios.

\section{Materials and methods}

\subsection{Sewage sludge and char}

Table 1 provides a brief characterization of both the anaerobically digested and thermally dried sewage sludge (SS), on which the study is based, and the char obtained experimentally from the pyrolysis of this sewage sludge. This characterization includes the proximate and ultimate analyses, heating value and specific heat capacity of the solids (Cp). Proximate analyses were performed according to standard methods (ISO- 
589-1981 for moisture, ISO-1171-1976 for ash and ISO-5623-1974 for volatiles), while the ultimate analyses were determined with a Carlo Erba EA1108 elemental analyzer. The higher heating value of the solids was measured with an IKA C-2000 calorimeter and its specific heat capacity was determined by differential scanning calorimetry using a Netzsch DSC 200 Maia Thermobalance (inert atmosphere: $40 \mathrm{~mL} \cdot \mathrm{min}^{-1}$ of nitrogen).

\subsection{Experimental setup}

Sewage sludge fast pyrolysis was performed in a lab-scale fluidized bed reactor operating at $530{ }^{\circ} \mathrm{C}$ and using $4.5 \mathrm{~m}^{3} \mathrm{STP} \cdot \mathrm{min}^{-1}$ of nitrogen (where STP means standard conditions of temperature and pressure at $0{ }^{\circ} \mathrm{C}$ and $1 \mathrm{~atm}$ ) as fluidizing agent. Two icecooled condensers and an electrostatic precipitator were used to condensate the produced vapors. The composition of the dry product gas was analyzed on-line with a micro gas chromatograph (Agilent 3000). The pyrolysis plant and the operating conditions are described in detail elsewhere [30]. The liquid collected after condensation of the vapors was separated into three phases: light organic phase (LOP), heavy organic phase (HOP) and aqueous phase (AP). The water content of each phase was analyzed by Karl Fischer titration (Mettler Toledo titrator), while its composition was qualitatively determined by gas chromatography-mass spectrometry (Hewlett Packard HP 5890 A). Ultimate analysis and higher heating value of each liquid phase were determined with a Leco TruSpec Micro elemental analyzer and an IKA C-2000 analytical calorimeter, respectively. As commented above, the solid by-product resulting from the pyrolysis process was also characterized and used as a raw material for the gasification process.

The experiments of sewage sludge gasification and char gasification were carried out in a lab-scale fluidized bed reactor operating at atmospheric pressure and in a temperature range of $770-850{ }^{\circ} \mathrm{C}$. More details about the gasification setup can be found 
elsewhere [31, 32]. Different mixtures of steam and air (or enriched air in order to ensure similar fluidization rates) were used as gasifying/fluidizing agent. The equivalence ratio (ratio of the actual fuel-to-oxygen ratio to the stoichiometric fuel-tooxygen ratio) varied from $12 \%$ to $32 \%$, while the steam to dry and ash-free (daf) biomass ratio (S/B) varied from 0.27 to $0.71 \mathrm{~kg} \cdot \mathrm{kg}^{-1}$ in both cases. The produced mixture of steam and tar was condensed in two ice-cooled condensers and its water content and qualitative composition were determined using the aforementioned equipment. The composition of the dry product gas was analyzed on-line with a micro gas chromatograph (Agilent 3000). The ultimate analyses of the solid by-products resulting from the gasification processes were determined with a Leco TruSpec Micro elemental analyzer and their higher heating values were calculated according to Dulong

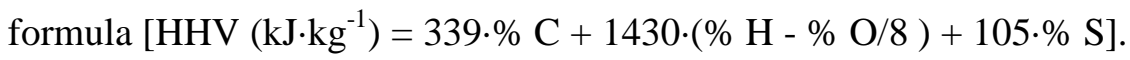

\section{Results and discussion}

The energetic assessment of the individual stages forming part of the processes shown in Fig. 1 (sewage sludge drying, sewage sludge gasification, sewage sludge pyrolysis and char gasification) is performed and discussed in this section. An overview of the total energy requirement for the two-stage and three-stage processes is also included at the end of the section.

\subsection{Sewage sludge thermal drying}

Prior to the thermo-chemical treatment of sewage sludge by means of pyrolysis or gasification, sewage sludge drying allows reduction of water content in the waste. Thermal drying of sewage sludge is not a waste elimination technique, but waste volume is reduced, which facilitates handling of the biosolids.

The heat needed for the sewage sludge thermal drying can be calculated as follows: 
where:

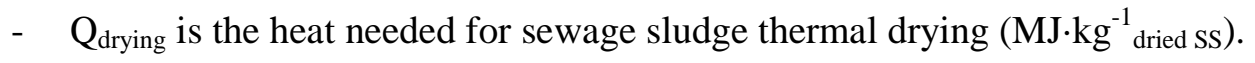

- $\quad \mathrm{m}_{\text {dried } \mathrm{Ss}}$ is the mass of dried sewage sludge (1 $\mathrm{kg}$ as calculation basis).

- $\mathrm{m}_{\mathrm{H} 2 \mathrm{O}, \mathrm{SS}}$ is the mass of water present in the sewage sludge before the thermal drying $\left(\mathrm{kg} \mathrm{kg}^{-1}\right.$ dried Ss).

- $\Delta \mathrm{T}$ is the difference between the temperature of the sewage sludge at the beginning and at the end of the drying process (from 25 to $100^{\circ} \mathrm{C}$ ).

- $\mathrm{Cp}_{\mathrm{SS}}$ is the specific heat capacity of the dried sewage sludge. This value was experimentally obtained at $25^{\circ} \mathrm{C}\left(1.15 \cdot 10^{-3} \mathrm{MJ} \cdot \mathrm{kg}^{-1} \cdot \mathrm{K}^{-1}\right)$ and has been considered constant with temperature for the calculations. The variation of $\mathrm{Cp}_{\mathrm{SS}}$ with temperature could not be obtained in the upper range of temperature because of the sewage sludge thermal decomposition observed during the measurement.

- $\quad \mathrm{Cp}_{\mathrm{H} 2 \mathrm{O}(1)}$ is the commonly used specific heat capacity for the liquid water $\left(4.18 \cdot 10^{-3}\right.$ $\left.\mathrm{MJ} \cdot \mathrm{kg}^{-1} \cdot \mathrm{K}^{-1}\right) . \mathrm{Cp}_{\mathrm{H} 2 \mathrm{O}(\mathrm{l})}$ is virtually constant in the temperature range considered for the sewage sludge thermal drying $\left(25-100{ }^{\circ} \mathrm{C}\right)$, only varying from $4.18 \cdot 10^{-3}$ to $4.22 \cdot 10^{-3} \mathrm{MJ} \cdot \mathrm{kg}^{-1} \cdot \mathrm{K}^{-1}[33]$.

- $\mathrm{m}_{\mathrm{H} 2 \mathrm{O} \text {,evap }}$ is the mass of water evaporated during the sewage sludge thermal drying $\left(\mathrm{kg} \cdot \mathrm{kg}^{-1}\right.$ dried SS$)$.

- $\Delta \mathrm{H}_{\mathrm{vap}, \mathrm{H} 2 \mathrm{O}}$ is the enthalpy of vaporization of water at the exit temperature $(2.26$ $\mathrm{MJ} \cdot \mathrm{kg}^{-1} \mathrm{H} 2 \mathrm{O}$ at $\left.100^{\circ} \mathrm{C}\right)[33]$.

Fig. 2 shows the evolution of the heat needed for sewage sludge drying as a function of the initial and final moisture contents, based on calculations performed with equation (1). For instance, almost $8 \mathrm{MJ} \cdot \mathrm{kg}^{-1}$ dried ss are required for reducing the water content from $77 \mathrm{wt} . \%$ to $6.5 \mathrm{wt} . \%$, which represent the actual data of the wastewater treatment 
plant in which the sewage sludge used was generated. However, the heat required for the sewage sludge thermal drying could be reduced by half if the initial moisture content is reduced from 77 to $65 \mathrm{wt}$. $\%$ by improving the efficiency of the prior mechanical dewatering of sewage sludge.

\subsection{Sewage sludge pyrolysis}

If negligible heat losses are considered in the reactor (adiabatic reactor), the heat of reaction for the pyrolysis of sewage sludge can be calculated from the enthalpies of the streams entering and exiting the reactor as follows:

$$
\mathrm{Q}=\Delta \mathrm{H}_{\mathrm{out}}-\Delta \mathrm{H}_{\mathrm{in}}
$$

where $\mathrm{Q}$ is the heat of pyrolysis reaction $\left(\mathrm{MJ} \cdot \mathrm{kg}^{-1} \mathrm{Ss}\right)$, and $\Delta \mathrm{H}_{\mathrm{in}}$ and $\Delta \mathrm{H}_{\text {out }}$ represent the enthalpies of the streams entering and exiting the reactor, respectively. According to equation (2), $\mathrm{Q}<0$ corresponds to an exothermic process, while $\mathrm{Q}>0$ refers to an endothermic process.

The total enthalpy of each stream $(\Delta \mathrm{H})$ can be calculated from equation (3):

$$
\Delta \mathrm{H}=\sum_{\mathrm{i}} \mathrm{m}_{\mathrm{i}} \cdot\left(\Delta \mathrm{H}_{\mathrm{f}, \mathrm{i}}^{\mathrm{o}}+\int_{\mathrm{T}_{\mathrm{ref}}}^{\mathrm{T}} \mathrm{Cp} \mathrm{p}_{\mathrm{i}}(\mathrm{T}) \cdot \mathrm{dT}\right)
$$

where:

- $\quad \mathrm{m}_{\mathrm{i}}$ is the mass flow rate of each compound forming part of the streams $\left(\mathrm{kg}^{\mathrm{kg}} \mathrm{kg}^{-1} \mathrm{ss}\right)$. $1 \mathrm{~kg}$ of sewage sludge was used as calculation basis. The mass flow rates of the products have been calculated according to the experimental yields obtained in the pyrolysis process (Table 2).

- $\mathrm{T}_{\text {ref }}$ is the reference temperature $(298 \mathrm{~K})$ and $\mathrm{T}(\mathrm{K})$ is the temperature of each stream. The inlet streams (sewage sludge and nitrogen) were at ambient temperature $(298 \mathrm{~K})$, the same as the outlet stream of gases and vapors, which was cooled down to ambient temperature in order to take advantage of their sensible and 
latent heats. The solid product (char) was considered to leave the reactor at the pyrolysis temperature (803 K).

- $\Delta \mathrm{H}_{\mathrm{f}, \mathrm{i}}^{\mathrm{o}}$ is the standard enthalpy of formation $\left(\mathrm{MJ}^{\mathrm{kg}} \mathrm{kg}^{-1}\right)$ of each compound at the reference temperature $(298 \mathrm{~K})$. The $\Delta \mathrm{H}_{\mathrm{f}}^{\mathrm{o}}$ data of the gases involved in the process can be easily found in the literature [33]. The $\Delta \mathrm{H}_{\mathrm{f}}^{\mathrm{o}}$ data corresponding to the solid materials (sewage sludge and char) and to the liquid phases (LOP, HOP and AP) have been calculated from their ultimate analyses and heating values according to the following equation:

$$
\Delta \mathrm{H}_{\mathrm{f}, \mathrm{i}}^{\mathrm{o}}=\left(\sum_{\mathrm{j}} \mathrm{m}_{\mathrm{j}} \cdot \Delta \mathrm{H}_{\mathrm{f}, \mathrm{j}}^{\mathrm{o}}\right)+\mathrm{HHV}
$$

where ' $\mathrm{j}$ ' represents each product derived from the complete combustion of the material $\left(\mathrm{CO}_{2}, \mathrm{H}_{2} \mathrm{O}, \mathrm{SO}_{2}\right.$ and $\left.\mathrm{NO}\right), \mathrm{m}_{\mathrm{j}}$ is the mass of each combustion gas produced per kilogram of material, $\Delta \mathrm{H}_{\mathrm{f}, \mathrm{j}}^{\mathrm{o}}$ is the standard enthalpy of formation of each combustion gas and HHV is the higher heating value of the solid material or liquid phase (Table 2). This way of calculating the $\Delta \mathrm{H}_{\mathrm{f}}^{\mathbf{o}}$ does not include the $\Delta \mathrm{H}_{\mathrm{f}}^{\mathbf{o}}$ corresponding to the ash content in the solids, but this data is not necessary for the calculations because ash is an inert material during the process and the contribution of its $\Delta \mathrm{H}_{\mathrm{f}}^{\mathrm{o}}$ is simplified in the energy balance. The $\Delta \mathrm{H}_{\mathrm{f}}^{\mathrm{o}}$ of the sewage sludge was found to be $-3.28 \mathrm{MJ} \cdot \mathrm{kg}^{-1}$ SS (note that this value does not include the $\Delta \mathrm{H}_{\mathrm{f}}^{\mathrm{o}}$ of the ash content). Data of the $\Delta \mathrm{H}_{\mathrm{f}}^{\mathrm{o}}$ of the products of the pyrolysis process are summarized in Table 2.

- $C p_{i}(T)$ is the specific heat capacity of each compound as a function of the temperature $\left(\mathrm{MJ} \cdot \mathrm{kg}^{-1} \cdot \mathrm{K}^{-1}\right)$. Only the temperature of the solid product $(803 \mathrm{~K})$ was different from the reference value (298 K), thus only the Cp (T) of char was taken into account in the energy balance. However, the variation of $\mathrm{Cp}$ of char with temperature could not be obtained up to the pyrolysis temperature (803 K) because 
of operational limitations of the thermobalance used, so that the $\mathrm{Cp}$ of the char has been considered constant with temperature for the calculations, using an experimental value obtained at an intermediate temperature $\left(1.21 \cdot 10^{-3} \mathrm{MJ} \cdot \mathrm{kg}^{-1} \cdot \mathrm{K}^{-1}\right.$ at $573 \mathrm{~K})$.

According to this procedure, the heat of pyrolysis reaction (including the cooling and condensation of the vapors) was found to be around $-0.70 \mathrm{MJ} \cdot \mathrm{kg}^{-1} \mathrm{ss}$. This indicates that, in the absence of significant heat losses and if the heat released from the cooling and condensation of the gases and vapors could be efficiently used, sewage sludge pyrolysis could be an autothermal process.

The energy demand corresponding only to the thermal decomposition of sewage sludge, without including the energy recovery from gases and vapors, has also been approximately calculated. In this case, gases and vapors were considered to leave the reactor at the pyrolysis temperature, that is, in gas phase. The following assumptions have been considered for performing the energy balance:

- The composition of each liquid phase was simplified by considering only its water content and one representative organic compound: cholest-4-ene for the LOP, 3methyl-phenol for the HOP and acetic acid for the AP. These were some of the compounds detected by GC-MS with the largest chromatographic area. The mass of the representative species in each phase was equated to the mass of the whole organic fraction of the phase. This assumption affects the actual $\mathrm{Cp}$ and $\Delta \mathrm{H}_{\mathrm{vap}}$ of the liquid phases, but should not result in misleading calculations since the properties of the main organic compounds present in each phase are similar to each other.

- Although the aforementioned organic compounds were in gas phase in the outlet stream, $\mathrm{Cp}(\mathrm{T})$ of these compounds in liquid phase were also required, as well as 
their enthalpies of vaporization, since the temperature range in the integer included in equation (3) involves a phase change for the produced vapors $\left(\mathrm{T}_{\mathrm{ref}}=298 \mathrm{~K}, \mathrm{~T}=\right.$ $803 \mathrm{~K})$.

- The equation of Harrison and Seaton [34] was used for calculating the Cp of the representative organic compounds in liquid phase (considered constant with temperature), while the $\mathrm{Cp}$ data of the compounds in gas phase were found in the literature as a function of temperature. The global $\mathrm{Cp}$ of each phase (both in liquid and gas phases) can be estimated as a weighted average of the specific heat capacities of water (or steam) and of the representative organic compound of each phase. The results are presented in Table 2 .

- In the same way, the enthalpy of vaporization of the liquid phases $\left(\Delta \mathrm{H}_{\mathrm{vap}}\right)$ was estimated as a weighted average of the enthalpies of vaporization of the water and of the representative organic compound of each phase at their boiling temperatures. These results are also presented in Table 2 .

According to this procedure, the energy demand for the thermal decomposition of sewage sludge was around $0.15 \mathrm{MJ} \cdot \mathrm{kg}^{-1}$ ss. This value is lower than other decomposition heats found in the literature for other types of biomass because of the higher ash content in sewage sludge, which is not decomposed during the process. For example, a decomposition heat of $0.3 \mathrm{MJ} \cdot \mathrm{kg}^{-1}$ has been reported for pyrolysis of crop residues [29]. Different water contents in the sewage sludge will also affect the energy demand for its thermal decomposition.

\subsection{Air-steam gasification of both sewage sludge and char}

In addition to the energetic assessment of the sewage sludge gasification and the char gasification performed with experimental data, a theoretical study performed with equilibrium data is also presented in this section in order to further study the 
gasification stages and find their thermodynamic restrictions. Experimental and equilibrium data are compared in this section.

\subsubsection{Energetic assessment according to experimental results}

Gasification experiments were performed under allothermal conditions, as the gasifier required external heat in order to maintain the gasification temperature. If negligible heat losses are considered in the gasifier, the heat of reaction for the air-steam gasification of both raw materials, sewage sludge and char, can be calculated according to equation (2). The total $\Delta \mathrm{H}$ of each stream was calculated as shown in equation (3), considering the following data:

- $1 \mathrm{~kg}$ of raw material (sewage sludge or char) has been used as calculation basis in both gasification processes. The amount fed of gasifying agent varied depending on the equivalence ratio (ER) and the steam to biomass daf ratio $(\mathrm{S} / \mathrm{B})$ defined in each case. Tables 3 and 4 present the mass flow rates of the products experimentally obtained in sewage sludge gasification and char gasification under different operating conditions, respectively [31, 32].

- The raw material (sewage sludge or char) and the air stream were at ambient temperature $(298 \mathrm{~K})$ at the gasifier inlet, while steam was generated and fed at 448 K. All the products (gas, solid, steam and tar) left the gasifier at the gasification temperature (1043-1123 K).

- The collected amount of tar was simplified to an equimolar mixture of benzene, naphthalene and pyridine, since these were some of the main compounds detected in the tar mixtures by GC-MS [31]. As mass yield of tar is much lower than the other products, its contribution to the energy balance is also less important, so this assumption should not result in misleading calculations. 
- The $\Delta \mathrm{H}_{\mathrm{f}}^{\mathrm{o}}$ and $\mathrm{Cp}(\mathrm{T})$ of the gases and vapors involved in the process $\left(\mathrm{N}_{2}, \mathrm{O}_{2}, \mathrm{H}_{2}\right.$, $\mathrm{CO}, \mathrm{CO}_{2}, \mathrm{CH}_{4}, \mathrm{C}_{2} \mathrm{H}_{2}, \mathrm{C}_{2} \mathrm{H}_{4}, \mathrm{C}_{2} \mathrm{H}_{6}, \mathrm{H}_{2} \mathrm{~S}$, steam, benzene, naphthalene and pyridine) were taken from the literature [33]. The $\Delta \mathbf{H}^{\mathbf{o}}$ of the solid by-products was calculated according to equation (4).

- The Cp (T) of the solid by-products was approximated to that of sewage sludge combustion ash because these solids were mainly composed of ash. The ash content was higher than 93 wt. \% in most cases $[31,32]$. The Cp (T) of the sewage sludge ash was experimentally measured by DSC but, because of operational limitations of the thermobalance used, the variation of $\mathrm{Cp}$ with temperature could not be obtained up to 1043-1123 K, which is the upper limit of the integer in equation (3). Thus, the $\mathrm{Cp}$ of the solid by-products was considered constant with temperature and an experimental value measured at an intermediate temperature $\left(1.07 \cdot 10^{-3} \mathrm{MJ} \cdot \mathrm{kg}^{-1} \cdot \mathrm{K}^{-1}\right.$ at $773 \mathrm{~K}$ ) was used for calculations.

The experimental heats of reaction obtained for the gasification of sewage sludge and char under different experimental conditions are depicted in Figs. 3a and $3 \mathrm{~b}$. Despite the lower organic content in the char than in the sewage sludge (Table 1), the external energy demand for gasifying $1 \mathrm{~kg}$ of char was higher than that for gasifying 1 $\mathrm{kg}$ of sewage sludge. For instance, the heat of reaction for sewage sludge gasification with $\mathrm{ER}=17 \%$ and $\mathrm{S} / \mathrm{B}=0.71$ was $0.64 \mathrm{MJ} \cdot \mathrm{kg}^{-1}$ at $850{ }^{\circ} \mathrm{C}$ and $0.17 \mathrm{MJ} \cdot \mathrm{kg}^{-1}$ at $770{ }^{\circ} \mathrm{C}$, while it reached $1.00 \mathrm{MJ} \cdot \mathrm{kg}^{-1}$ and $0.78 \mathrm{MJ} \cdot \mathrm{kg}^{-1}$ for char gasification at 850 and $770{ }^{\circ} \mathrm{C}$, respectively. This behavior could be related to the observed changes in the organic structure of sewage sludge after carrying out the pyrolysis process. The fraction of volatile matter was higher in the sewage sludge than in the char, while the fraction of fixed carbon was higher in the char (Table 1). This means that combustion reactions in gas phase, which usually show less diffusional resistance than the solid-gas reactions, 
occur to a greater extent during the sewage sludge gasification. In the case of char gasification, the main combustion reactions in gas phase involve gases such as $\mathrm{H}_{2}$ or $\mathrm{CO}$ (produced from fixed carbon reactions), whose calorific value is lower than that of hydrocarbons, so that less energy is released from these combustion reactions. As a consequence, char gasification was an endothermic process under almost all the experimental conditions used, while sewage sludge gasification was an exothermic process when simultaneously working with $\mathrm{ER}>19 \%$ and $\mathrm{S} / \mathrm{B}<0.52$. The heat of reaction (based on experimental data) ranged from -2.61 to $+1.29 \mathrm{MJ} \cdot \mathrm{kg}^{-1}$ ss for sewage sludge gasification and from -0.23 to $+1.20 \mathrm{MJ} \cdot \mathrm{kg}^{-1}$ char for char gasification. Therefore, the temperature and the gasification medium play a larger role in the energy balance of sewage sludge gasification.

The energy demand for carrying out an endothermic gasification process may be obtained from the product gas, either from its thermal energy (by putting the product gas and the inlet air stream in contact in a heat exchanger to preheat the air before entering the gasifier) or from combustion of part of the gas. The gasification efficiency can be defined as the fraction of the energy initially contained in the raw material that could be recovered from the product gas after carrying out the gasification process (5):

$$
\begin{aligned}
& \text { Gasification efficency }(\%) \\
& \qquad=\frac{\text { Energy in gas }-Q_{\text {gasification }}-\text { Energy for steam generation }}{L H V_{\text {raw material }}} \cdot 100
\end{aligned}
$$

where:

- "Energy in gas" is the energy that could be recovered from the gasification product gas $\left(\mathrm{MJ} \cdot \mathrm{kg}^{-1}\right.$ raw material), both from its thermal energy and from its calorific value (6). A heat exchange efficiency of $70 \%$ has been considered when taking advantage of the sensible and latent heats of the gas stream [35]. 


$$
\begin{aligned}
& \text { Energy in gas }=\eta_{\text {gas }} \cdot \mathrm{LHV}_{\text {gas }}+0.7 \cdot\left[\sum_{\mathrm{i}} \mathrm{m}_{\mathrm{i}, \text { gas }} \cdot \int_{\mathrm{T}_{\text {ref }}}^{\mathrm{T}} \mathrm{Cp}_{\mathrm{i}, \text { gas }}(\mathrm{T}) \cdot \mathrm{dT}\right]+0.7 \cdot \mathrm{m}_{\mathrm{H}_{2} \mathrm{O}} \\
& \cdot\left[\mathrm{Cp}_{\mathrm{H}_{2} \mathrm{O}(\mathrm{l})} \cdot\left(\mathrm{T}_{\mathrm{b}, \mathrm{H}_{2} \mathrm{O}}-\mathrm{T}_{\text {ref }}\right)+\Delta \mathrm{H}_{\text {cond. } \mathrm{H}_{2} \mathrm{O}}+\int_{\mathrm{T}_{\mathrm{b}, \mathrm{H} 2 \mathrm{O}}}^{\mathrm{T}} \mathrm{Cp}_{\mathrm{H}_{2} \mathrm{O}(\mathrm{v})}(\mathrm{T}) \cdot \mathrm{dT}\right]+0.7 \cdot \sum_{\mathrm{i}, \mathrm{tar}} \mathrm{m}_{\mathrm{i}, \mathrm{tar}} \\
& \cdot\left[\mathrm{Cp}_{\mathrm{i}, \operatorname{tar}(\mathrm{l})} \cdot\left(\mathrm{T}_{\mathrm{b} i, \operatorname{tar}}-\mathrm{T}_{\text {ref }}\right)+\Delta \mathrm{H}_{\text {cond.i,tar }}+\int_{\mathrm{T}_{\mathrm{b}, \mathrm{tar}}}^{\mathrm{T}} \mathrm{Cp}_{\mathrm{i}, \operatorname{tar}(\mathrm{v})}(\mathrm{T}) \cdot \mathrm{dT}\right]
\end{aligned}
$$

being $\eta_{\text {gas }}$ the dry gas yield $\left(\mathrm{m}^{3}{ }_{\text {STP }} \cdot \mathrm{kg}^{-1}\right.$ raw material, Tables 3 and 4$), \mathrm{LHV}_{\text {gas }}$ the lower heating value of the dry gas $\left(\mathrm{MJ} \cdot \mathrm{m}^{-3}\right.$ STP, Tables 3 and 4$), \mathrm{m}_{\mathrm{i}, \text { gas }}$ the mass flow rate of the non-condensable gases $\left(\mathrm{kg} \cdot \mathrm{kg}^{-1}\right.$ raw material, Tables 3 and 4$), \mathrm{T}_{\text {ref }}=298 \mathrm{~K}$, $\mathrm{T}$ the gasification temperature $(\mathrm{K}), \mathrm{Cp}_{\mathrm{i} \text {,gas }}(\mathrm{T})$ the specific heat capacity of the noncondensable gases as a function of temperature $\left(\mathrm{MJ} \cdot \mathrm{kg}^{-1} \cdot \mathrm{K}^{-1}\right)[33], \mathrm{m}_{\mathrm{H} 2 \mathrm{O}}$ the mass flow rate of produced water $\left(\mathrm{kg} \cdot \mathrm{kg}^{-1}\right.$ raw material, Tables 3 and 4$), \mathrm{Cp}_{\mathrm{H} 2 \mathrm{O}(\mathrm{l})}$ the specific heat capacity of liquid water $\left(4.18 \cdot 10^{-3} \mathrm{MJ} \cdot \mathrm{kg}^{-1} \cdot \mathrm{K}^{-1}\right), \mathrm{T}_{\mathrm{b}, \mathrm{H} 2 \mathrm{O}}$ the boiling point of water $(373 \mathrm{~K}), \Delta \mathrm{H}_{\text {cond.H2O }}$ the enthalpy of condensation of water at its boiling point $\left(2.26 \mathrm{MJ} \cdot \mathrm{kg}^{-1}\right), \mathrm{Cp}_{\mathrm{H} 2 \mathrm{O}(\mathrm{v})}(\mathrm{T})$ the specific heat capacity of steam as a function of temperature [33], $\mathrm{m}_{\mathrm{i}, \text { tar }}$ the mass flow rates of tar components $\left(\mathrm{kg} \cdot \mathrm{kg}^{-1}\right.$ raw material), $C \mathrm{p}_{\mathrm{i}, \operatorname{tar}(1)}$ the specific heat capacity of tar components in liquid phase (calculated according to [34]), $\mathrm{T}_{\mathrm{bi}, \mathrm{tar}}$ the boiling point of tar components, $\Delta \mathrm{H}_{\mathrm{cond} ., \mathrm{tar}}$ the enthalpy of condensation of tar components at their boiling points $(0.39,0.34$ and 0.44 $\mathrm{MJ} \cdot \mathrm{kg}^{-1}$ for benzene, naphthalene and pyridine, respectively) and $\mathrm{Cp}_{\mathrm{i}, \operatorname{tar}(\mathrm{v})}(\mathrm{T})$ the specific heat capacity of tar components in gas phase as a function of temperature. The obtained results of "energy in gas" are shown in Table 5.

- $\mathrm{Q}_{\text {gasification }}$ is the heat of reaction for the gasification process ( $\mathrm{MJ} \cdot \mathrm{kg}^{-1}$ raw material), which has been previously calculated according to equation (2) under different experimental conditions (Figs. 3a and 3b).

- "Energy for steam generation" $\left(\mathrm{MJ} \cdot \mathrm{kg}^{-1}\right.$ raw material $)$ is the energy demand for heating and evaporating the inlet flow of water from $25^{\circ} \mathrm{C}$ to $150{ }^{\circ} \mathrm{C}\left(2.36 \mathrm{MJ} \cdot \mathrm{kg}^{-1} \mathrm{H} 2 \mathrm{O}\right)$. 


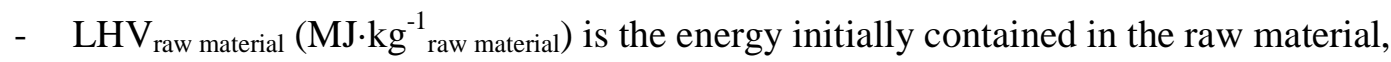
expressed as its lower heating value (Table 1).

The efficiency results for sewage sludge gasification and char gasification are presented in Table 5. Experimental efficiency data varied from 58\% to $87 \%$ for sewage sludge gasification and from $23 \%$ to $64 \%$ for char gasification. Better results were obtained for the sewage sludge gasification than for the char gasification since the heat of reaction was lower in the first case, and also more energy can be recovered from the product gas of sewage sludge gasification, mainly due to the higher gas yield (Tables 3 and 4). The gasification efficiency (based on experimental data) was improved at higher temperatures, higher ER and lower S/B.

\subsubsection{Energetic assessment according to equilibrium data}

The heat of reaction for the air-steam gasification of sewage sludge and char when reaching the chemical equilibrium is determined in this section. The calculation has been carried out analogously to section 3.3.1, but in this case the product mass flows were not experimental data, but equilibrium calculated data. HSC Chemistry® 6.1 software was used to determine the mass flow rates of the products at equilibrium conditions. This software uses the Gibbs energy minimization method to calculate the amounts of products at equilibrium in isothermal and isobaric conditions. Therefore, the reaction system (temperature, pressure, feed of gasifying agent, amounts of $\mathrm{C}, \mathrm{H}, \mathrm{O}, \mathrm{S}$ and $\mathrm{N}$ that form part of the organic fraction of the raw material and the species expected to be part of the products) must be specified for the calculations.

The main compounds found in the product gas at equilibrium conditions were $\mathrm{H}_{2}$, $\mathrm{CO}, \mathrm{CO}_{2}, \mathrm{CH}_{4}, \mathrm{H}_{2} \mathrm{~S}, \mathrm{NH}_{3}, \mathrm{~N}_{2}$ and steam. Neither tar nor light hydrocarbons, except $\mathrm{CH}_{4}$, were formed at equilibrium conditions. In addition to gas production, a small 
fraction of the initial carbon contained in the raw material (sewage sludge or char) remained in the solid by-product under some operating conditions simulated.

The heats of reaction at chemical equilibrium and at the same operating conditions used in the laboratory are depicted in Figs. $3 \mathrm{c}$ and $3 \mathrm{~d}$ as a comparison to the experimental data (Figs. 3a and 3b). As can be observed, reaching the chemical equilibrium in both gasification processes entails additional energy consumption. The reason may be the predominance of endothermic equilibrium reactions during the gasification, such as carbon reforming $\left(\mathrm{C}+\mathrm{H}_{2} \mathrm{O} \leftrightarrow \mathrm{CO}+\mathrm{H}_{2}, \Delta \mathrm{H}_{298 \mathrm{~K}}=131.4 \mathrm{~kJ} \cdot \mathrm{mol}^{-1}\right)$, dry reforming $\left(\mathrm{CH}_{4}+\mathrm{CO}_{2} \leftrightarrow 2 \mathrm{CO}+2 \mathrm{H}_{2}, \Delta \mathrm{H}_{298 \mathrm{~K}}=246.8 \mathrm{~kJ} \cdot \mathrm{mol}^{-1}\right)$, the Boudouard reaction $\left(\mathrm{C}+\mathrm{CO}_{2} \leftrightarrow 2 \mathrm{CO}, \Delta \mathrm{H}_{298 \mathrm{~K}}=172.3 \mathrm{~kJ} \cdot \mathrm{mol}^{-1}\right)$ and the methanation reaction $(\mathrm{CO}$ $+3 \mathrm{H}_{2} \leftrightarrow \mathrm{CH}_{4}+\mathrm{H}_{2} \mathrm{O}, \Delta \mathrm{H}_{298 \mathrm{~K}}=76.8 \mathrm{~kJ} \cdot \mathrm{mol}^{-1}$ ), against the exothermic equilibrium reactions, such as the water-gas shift reaction $\left(\mathrm{CO}+\mathrm{H}_{2} \mathrm{O} \leftrightarrow \mathrm{CO}_{2}+\mathrm{H}_{2}, \Delta \mathrm{H}_{298 \mathrm{~K}}=-40.9\right.$ $\mathrm{kJ} \cdot \mathrm{mol}^{-1}$ ). These reactions occur to a greater extent at equilibrium, which shows the thermodynamic limit of the process.

As can be seen in Fig. 3, gasification of sewage sludge at equilibrium conditions only resulted in an exothermic process when ER was increased to $32 \%$. The char gasification at equilibrium conditions was an endothermic process in all the simulated cases. However, the gas heating value and the gas yield calculated for equilibrium conditions were higher than those obtained experimentally [31, 32], so more energy can be recovered from the product gas at equilibrium conditions (Table 5). This difference outweighs the difference observed in the experimental and equilibrium data of heat of reaction (Fig. 3), so the gasification efficiency is improved at equilibrium conditions: 90-94\% for sewage sludge gasification and $78-84 \%$ for char gasification (Table 5).

As an extension of the theoretical study, Fig. 4 shows the evolution of the heat of reaction for air-steam gasification of both sewage sludge and char as a function of the 
feed of oxygen and steam, which are represented by ER and S/C (steam to carbon molar ratio), respectively. Two different gasification temperatures $\left(800\right.$ and $850{ }^{\circ} \mathrm{C}$ ) have been used for the calculations. Operating temperatures above $800{ }^{\circ} \mathrm{C}$ are usually preferred in gasification processes in order to achieve high carbon conversion and low tar content in the product gas [36]. The heat of reaction for both gasification processes at equilibrium conditions decreases with the higher availability of oxygen (higher ER enhances the combustion reactions) and/or with the lower presence of steam (lower S/C reduces the extension of the endothermic steam reforming reactions). For example, for ER $=20 \%$ and $\mathrm{S} / \mathrm{C}=0-1$, an external heat transfer of $2.01-2.43 \mathrm{MJ} \cdot \mathrm{kg}^{-1}$ ss and $1.36-1.86 \mathrm{MJ} \cdot \mathrm{kg}^{-1}$ char would be required in order to maintain a temperature of $850{ }^{\circ} \mathrm{C}$ during the gasification of sewage sludge and char at equilibrium conditions, respectively. In the lower range of ER (up to $25 \%$ ), energy demand for gasifying $1 \mathrm{~kg}$ of char is lower than that required for gasifying $1 \mathrm{~kg}$ of sewage sludge, but this trend is reversed in the upper range of ER since the energy released from the in situ combustion of sewage sludge becomes more important.

If the gasifier operates at autothermal conditions instead of being heated by external heat transfer, the gasification temperature is the output variable of the energy balance, being the result of balancing out the enthalpies of the streams entering and exiting the gasifier $\left(\Delta \mathrm{H}_{\mathrm{in}}=\Delta \mathrm{H}_{\mathrm{out}}\right.$, assuming negligible heat losses $)$. The gasification temperature at equilibrium conditions has been calculated under different gasification mediums following an iterative method: $\Delta \mathrm{H}_{\text {out }}$ depends on the mass flow rates of the product (3), and these in turn depend on the gasification temperature (the temperature has to be specified in the HSC Chemistry software to calculate the amounts of products at equilibrium). Fig. 5 shows the evolution of the equilibrium temperature as a function of ER and S/C for air-steam gasification of both sewage sludge and char. Obviously, the 
equilibrium temperature is increased with ER and decreased with S/C. Furthermore, the required ER to maintain a specific reaction temperature is higher in char gasification than in sewage sludge gasification. For instance, an ER of $33 \%$ would be required for the autothermal operation of sewage sludge gasification at $800{ }^{\circ} \mathrm{C}$ and $\mathrm{S} / \mathrm{C}=0.5$ under equilibrium conditions, while this value reaches $45 \%$ in the case of char gasification. The higher the ER, the greater the production of $\mathrm{CO}_{2}$ through combustion reactions. The presence of $\mathrm{CO}_{2}$ in the gasification gas is undesirable since it implies both a dilution effect of the gas heating value and a reduction in the formation of $\mathrm{CO}$, as the production and consumption of $\mathrm{CO}$ and $\mathrm{CO}_{2}$ are connected by reactions such as the water-gas shift or the Boudouard reaction. In addition to the gas calorific value, the $\mathrm{H}_{2} / \mathrm{CO}$ ratio in the product gas is an important parameter for using this gas as a feedstock in processes such as methanol or Fischer Tropsch synthesis. Values of this ratio close to 2 are usually required in these processes [37]. For the aforementioned example (ER of $33 \%$ for sewage sludge gasification and $45 \%$ for char gasification to maintain $800{ }^{\circ} \mathrm{C}$ with $\mathrm{S} / \mathrm{C}=$ $0.5), 44 \%$ of the carbon initially contained in the sewage sludge produces $\mathrm{CO}_{2}$, while this value reaches $52 \%$ in the case of char gasification. Both the heating value and the $\mathrm{H}_{2} / \mathrm{CO}$ ratio in the product gas resulting from sewage sludge gasification $\left(\mathrm{LHV}_{\text {gas }}=\right.$ 4.27 $\mathrm{MJ} \cdot \mathrm{m}^{3}{ }_{\mathrm{STP}}, \mathrm{H}_{2} / \mathrm{CO}=1.47$ ) are higher than those obtained for char gasification $\left(\mathrm{LHV}_{\text {gas }}=3.05 \mathrm{MJ} \cdot \mathrm{m}_{\text {STP }}^{3}, \mathrm{H}_{2} / \mathrm{CO}=0.89\right)$.

\subsection{Energetic assessment of the whole processes}

This last section presents an overall energetic assessment of the two thermochemical processes proposed in Fig. 1 for sewage sludge treatment: (i) sewage sludge drying + sewage sludge gasification (two-stage process) and (ii) sewage sludge drying + sewage sludge pyrolysis + char gasification (three-stage process). The total energy demand for the whole processes is the sum of the net heats required or released in the 
involved stages (positive term for endothermic processes and negative value for exothermic processes). Experimental data resulting from the pyrolysis and gasification stages have been used for the calculations:

- Sewage sludge drying. The water content in the sewage sludge is assumed to be reduced from 65 wt. \% (typical content of moisture in sewage sludge before its thermal drying) to $6.5 \mathrm{wt}$. \% during the thermal drying. For this case, $\mathrm{Q}_{\text {drying }}$ is around $4 \mathrm{MJ} \cdot \mathrm{kg}^{-1}$ dried SS (Fig. 2).

- Sewage sludge pyrolysis. The energy contained in the produced gases and vapors could be recovered to be used in the thermal decomposition of sewage sludge itself and in the prior thermal drying. This energy was calculated analogously to the gasification gas energy according to equation (6). An energy recovery of -1.32 $\mathrm{MJ} \cdot \mathrm{kg}^{-1}$ SS was obtained, which turns into $-1.17 \mathrm{MJ} \cdot \mathrm{kg}^{-1} \mathrm{ss}$ if the thermal decomposition heat is subtracted $\left(+0.15 \mathrm{MJ} \cdot \mathrm{kg}^{-1} \mathrm{ss}\right)$. The calorific value of the organic liquid product (43 MJ. $\mathrm{kg}^{-1}{ }_{\mathrm{LOP}}$ and $32 \mathrm{MJ} \cdot \mathrm{kg}^{-1}{ }_{\mathrm{HOP}}$ ) has not been included in the energy balance, as some important properties such as its poor stability or its high nitrogen content must be improved facing toward its use as fuel [7].

- Sewage sludge gasification/char gasification. The net heat of each gasification stage corresponds to the numerator of the equation (5), which was used to calculate the gasification efficiency: "Energy in gas" (as a negative term) - Q Qasification - "Energy for steam generation". As the same calculation basis is required for the comparison of the two-stage and three-stage processes (1 kg of sewage sludge fed in the pyrolysis process and in the gasification process), data corresponding to the gasification of char ( $\mathrm{MJ} \cdot \mathrm{kg}^{-1}$ char) must be turned into $\mathrm{MJ} \cdot \mathrm{kg}^{-1} \mathrm{SS}$ by means of the char yield obtained during the pyrolysis of sewage sludge $\left(0.519 \mathrm{~kg}_{\mathrm{char}} \cdot \mathrm{kg}^{-1} \mathrm{ss}\right)$. 
Fig. 6 shows the total energy requirement for the whole processes, considering the different experimental conditions used in the gasification stages. The total energy demand ranged between -2.83 and $-6.21 \mathrm{MJ} \cdot \mathrm{kg}^{-1}$ ss for the two-stage process (exothermic process) and between +1.17 and $+2.24 \mathrm{MJ} \cdot \mathrm{kg}^{-1}$ ss for the three-stage process (endothermic process). Thus, if the energy contained in the product gas of sewage sludge gasification could be efficiently used, it would be enough to cover the energy demand for both the sewage sludge thermal drying and the gasification process itself. On the other hand, the energy balance shows that the three-step treatment is globally an endothermic process (note that the use of calorific value of the pyrolysis liquid is not considered), so that an additional energy input would be needed to carry out this treatment. However, assuming a direct and efficient use of calorific value of the pyrolysis liquid organic fraction (3.92 $\left.\mathrm{MJ} \cdot \mathrm{kg}^{-1} \mathrm{ss}\right)$, a favorable energetic assessment of the three-stage process could also be obtained, with a total energy demand ranging from -2.75 to $-1.68 \mathrm{MJ} \cdot \mathrm{kg}^{-1}$ ss (exothermic process). Therefore, the use of the calorific value of the produced pyrolysis liquid is a key issue for reaching an autothermal three-stage process that does not require external heat to take place.

Regarding the influence of the gasification operating conditions on the total energy demand of the whole processes, the energy balance was more favorable at the highest gasification temperature $\left(850^{\circ} \mathrm{C}\right)$, the highest ER $(32 \%)$ and a moderate S/B (0.39).

\section{Conclusions}

This paper presents an energetic assessment of two potential thermo-chemical treatments for sewage sludge: (i) sewage sludge thermal drying + air-steam gasification of sewage sludge (two-stage process) and (ii) sewage sludge thermal drying + pyrolysis of sewage sludge + air-steam gasification of the char derived from the pyrolysis (threestage process). The sewage sludge thermal drying can drastically reduce the waste 
volume, which facilitates handling of the biosolids, but it involves high energy consumption. For example, $4 \mathrm{MJ} \cdot \mathrm{kg}^{-1}$ dried ss are required for reducing water content from 65 wt. $\%$ to 6.5 wt. $\%$. Regarding the pyrolysis stage, energetic calculations based on experimental yields showed that the energy needed for thermal decomposition of sewage sludge $\left(+0.15 \mathrm{MJ} \cdot \mathrm{kg}^{-1}\right.$ ss at $\left.530{ }^{\circ} \mathrm{C}\right)$ could be covered by the energy contained in the product stream of gases and vapors. An energy output of $-1.17 \mathrm{MJ} \cdot \mathrm{kg}^{-1} \mathrm{ss}$, recovered from the calorific value and the thermal energy of the product gas stream (given a heat exchange efficiency of $70 \%$ ), is still available for being used in the sewage sludge thermal drying after covering the energy demand for the pyrolysis reaction. Despite the lower organic content in the char (24.1 wt. \%) than in the sewage sludge (54.5 wt.\%), the external energy demand for gasifying $1 \mathrm{~kg}$ of char was higher than that for gasifying $1 \mathrm{~kg}$ of sewage sludge (based on experimental yields), which means that less energy is released from the in-situ combustion reactions during char gasification. Depending on the operating conditions, sewage sludge gasification was an exothermic or endothermic process and its heat of reaction varied from $-2.61 \mathrm{MJ} \cdot \mathrm{kg}^{-1} \mathrm{SS}\left(\mathrm{T}=770{ }^{\circ} \mathrm{C}\right.$, $\mathrm{ER}=32 \%, \mathrm{~S} / \mathrm{B}=0.39)$ to $+1.29 \mathrm{MJ} \cdot \mathrm{kg}^{-1} \mathrm{sS}\left(\mathrm{T}=850^{\circ} \mathrm{C}, \mathrm{ER}=12 \%, \mathrm{~S} / \mathrm{B}=0.52\right)$. Char gasification was an endothermic process in most of the experimental conditions, and its heat of reaction varied from $-0.23 \mathrm{MJ} \cdot \mathrm{kg}^{-1}$ char $\left(\mathrm{T}=770{ }^{\circ} \mathrm{C}, \mathrm{ER}=32 \%, \mathrm{~S} / \mathrm{B}=0.39\right)$ to $+1.20 \mathrm{MJ} \cdot \mathrm{kg}^{-1}{ }_{\text {char }}\left(\mathrm{T}=850{ }^{\circ} \mathrm{C}, \mathrm{ER}=12 \%, \mathrm{~S} / \mathrm{B}=0.52\right)$. A theoretical study performed with equilibrium data (calculated according to Gibbs energy minimization method) showed that both gasification processes require more energy to take place at equilibrium conditions. However, the gasification efficiency calculated at equilibrium conditions was higher than the experimental results because more energy can be recovered from the product gas obtained at equilibrium conditions. 
In summary, experimental data showed that the energy contained in the product gas of sewage sludge gasification is enough to cover the energy demand for both the sewage sludge thermal drying and the gasification process itself. However, an additional energy input is required to carry out the three-stage process. This energy demand could be provided by the calorific value of bio-oil produced in the pyrolysis stage, but some important properties such as its poor stability or its high nitrogen content must be improved facing toward its use as fuel.

\section{Acknowledgements}

The authors gratefully acknowledge the financial support provided by the Spanish Ministry of Science and Technology (research project CTQ2010-20137) and the Spanish Ministry of Education (pre-doctoral grant awarded to N.G.L, AP2009-3446).

\section{References}

[1] Werther J, Ogada T. Sewage sludge combustion. Prog. Energy Combust. Sci. 1999; 25:55-116.

[2] Council Directive 91/271/EEC of 21 May 1991 concerning urban waste water treatment.

[3] Fytili D, Zabaniotou A. Utilization of sewage sludge in EU application of old and new methods - A review. Renew. Sust. Energ. Rev. 2008; 12:116-40.

[4] Council Directive 86/278/EEC of 12 June 1986 on the protection of the environment, and in particular of the soil, when sewage sludge is used in agriculture.

[5] Furness DT, Hoggett LA, Judd SJ. Thermochemical treatment of sewage sludge. J. Chart. Inst. Water Environ. Manage. 2000; 14:57-65.

[6] Rulkens W, Sewage sludge as a biomass resource for the production of energy: Overview and assessment of the various options. Energy Fuels 2008; 22:9-15. 
[7] Fonts I, Gea G, Azuara M., Ábrego J, Arauzo J. Sewage sludge pyrolysis for liquid production: A review. Renew. Sustain. Energy Rev. 2012; 16:2781-805.

[8] Kim Y, Parker W. A technical and economic evaluation of the pyrolysis of sewage sludge for the production of bio-oil. Bioresour. Technol. 2008; 99:1409-16.

[9] Pokorna E, Postelmans N, Jenicek P, Schreurs S, Carleer R, Yperman J. Study of bio-oils and solids from flash pyrolysis of sewage sludges. Fuel 2009; 88:1344-50.

[10] Chaudhari ST, Dalai AK, Bakhshi NN. Production of hydrogen and/or syngas $\left(\mathrm{H}_{2}+\right.$ CO) via steam gasification of biomass-derived chars. Energy Fuels 2003; 17:106267.

[11] Haykiri-Acma H, Yaman S, Kucukbayrak S. Gasification of biomass chars in steam-nitrogen mixture. Energy Convers. Manag. 2006; 47:1004-13.

[12] He P, Luo S, Cheng G, Xiao B, Cai L, Wang J. Gasification of biomass char with air-steam in a cyclone furnace. Renew. Energy 2012; 37:398-402.

[13] Bacaicoa PG, Bilbao R, Uson C. Sewage sludge gasification: first studies. In Proceedings of the Second Biomass Conference of the Americas: Energy, Environment, and Agricultural Industry. 1995; 685-94.

[14] Adegoroye A, Paterson N, Li X, Morgan T, Herod AA, Dugwell DR, Kandiyoti R. The characterisation of tars produced during the gasification of sewage sludge in a spouted bed reactor. Fuel 2004; 83:1949-60.

[15] Manyá JJ, Sánchez JL, Gonzalo A, Arauzo J. Air gasification of dried sewage sludge in a fluidized bed: Effect of the operating conditions and in-bed use of alumina. Energy Fuels 2005; 19:629-36.

[16] Aznar M, Manyá JJ, García G, Influence of freeboard temperature, fluidization velocity and particle size on tar production and composition during the air gasification of sewage sludge. Energy Fuels 2008; 22:2840-50. 
[17] Tae-Young M, Bo-Sung K, Joo-Sik K. Production of a producer gas with high heating values and less tar from dried sewage sludge through air gasification using a two-stage gasifier and activated carbon. Energy Fuels 2009; 23:3268-76.

[18] Dogru M, Midilli A, Howarth CR. Gasification of sewage sludge using a throated downdraft gasifier and uncertainty analysis. Fuel Process. Technol. 2002; 75:55-82.

[19] Petersen I, Werther J. Experimental investigation and modelling of gasification of sewage sludge in the circulating fluidized bed. Chem. Eng. Process. 2005; 44:71736.

[20] Judex JW, Gaiffi M, Burgbacher HC. Gasification of dried sewage sludge: Status of the demonstration and the pilot plant. Waste Manage. 2012; 32:719-23.

[21] Nipattummakul N, Ahmed I, I Kerdsuwan S, Gupta AK. High temperature steam gasification of wastewater sludge. Appl. Energy 2010; 87:3729-34.

[22] Xu ZR, Zhu W, Li M. Influence of moisture content on the direct gasification of dewatered sludge via supercritical water. Int. J Hydrog. Energy 2012; 37:6527-35.

[23] McKendry P. Energy production from biomass (part 3): gasification technologies. Bioresour. Technol. 2002; 83:55-63.

[24] Franco C, Pinto F, Gulyurtlu I, Cabrita I. The study of reactions influencing the biomass steam gasification process. Fuel 2003; 82:835-42.

[25] Hosseini M, Dincer I, Rosen MA. Steam and air fed biomass gasification: Comparisons based on energy and exergy. Int. J. Hydrog. Energy 2012; 37:1644652.

[26] Karamarkovic R, Karamarkovic V. Energy and exergy analysis of biomass gasification at different temperatures. Energy 2010; 35:537-49.

[27] Ptasinski KJ, Prins MJ, Pierik A. Exergetic evaluation of biomass gasification, Energy $2007 ; 32: 568-74$. 
[28] Zhang Y, Li B, Li H, Zhang B. Exergy analysis of biomass utilization via steam gasification and partial oxidation. Thermochim. Acta 2012; 538:21-28.

[29] Manganaro J, Chen B, Adeosun J, Lakhapatri S, Favetta D, Lawal A. Conversion of residual biomass into liquid transportation fuel: an energy analysis. Energy Fuels $2011 ; 25: 2711-20$.

[30] Gil-Lalaguna N, Fonts I, Gea G, Murillo MB, Lázaro L, Reduction of water content in sewage sludge pyrolysis liquid by selective on-line condensation of the vapors. Energy Fuels 2010; 24:6555-64.

[31] Gil-Lalaguna N, Sánchez JL, Murillo MB, Rodríguez E, Gea G. Air-steam gasification of sewage sludge in a fluidized bed. Influence of some operating conditions. Chem. Eng. J. 2014; 248:373-82.

[32] Gil-Lalaguna N, Sánchez JL, Murillo MB, Ruiz V, Gea G. Air-steam gasification of char derived from sewage sludge pyrolysis. Comparison with the gasification of sewage sludge. Fuel 2014; 129:147-55.

[33] Perry RH, Green DW. Perry's Chemical Engineer's Handbook. $7^{\text {th }}$ ed. New York: McGraw-Hill; 1999.

[34] Harrison BK, Seaton WH. Solution to missing group-problem for estimation of ideal-gas heat-capacities. Ind. Eng. Chem. Res. 1988; 27:1536-40.

[35] Çengel YA. Heat and mass transfer: a practical approach. $3^{\text {rd }}$ ed. Mexico: McGrawHill Science/Engineering/Math; 2005.

[36] Devi L, Ptasinski KJ, Janssen FJJG. A review of the primary measures for tar elimination in biomass gasification processes. Biomass Bioenergy 2003; 24:125-40.

[37] Wender I. Reactions of synthesis gas. Fuel Process. Technol. 1996; 48:189-297. 
Table 1. Characterization of sewage sludge (SS) and char derived from sewage sludge pyrolysis.

\begin{tabular}{|c|c|c|}
\hline & SS & Char \\
\hline \multicolumn{3}{|c|}{ Proximate analysis (wt. \%, wet basis) } \\
\hline Moisture & 6.48 & 1.70 \\
\hline Ash & 39.04 & 74.20 \\
\hline Volatiles & 50.09 & 15.02 \\
\hline Fixed carbon & 4.39 & 9.08 \\
\hline \multicolumn{3}{|c|}{ Ultimate analysis (wt. \%, wet basis) } \\
\hline $\mathrm{C}$ & 29.50 & 15.49 \\
\hline $\mathrm{H}$ & 4.67 & 0.97 \\
\hline $\mathrm{N}$ & 5.27 & 1.85 \\
\hline $\mathrm{S}$ & 1.31 & 0.35 \\
\hline$L H V\left(M J \cdot \mathrm{kg}^{-1}\right)$ & 11.8 & 5.0 \\
\hline$C p_{25^{\circ} \mathrm{C}}\left(\mathrm{kJ} \cdot \mathrm{kg}^{-1} \cdot \mathrm{K}^{-1}\right)$ & 1.15 & 0.82 \\
\hline
\end{tabular}

29

30

31

32

33

34

35

36 
Table 2. Yields and properties of the products of the sewage sludge fast pyrolysis.

\begin{tabular}{|c|c|c|c|c|c|}
\hline $\begin{array}{l}\text { Yield } \\
\text { (wt. \%) }\end{array}$ & Composition & $\begin{array}{c}\mathrm{HHV} \\
\left(\mathrm{MJ} \cdot \mathrm{kg}^{-1}\right)\end{array}$ & $\begin{array}{c}\Delta \mathrm{H}_{\mathrm{f}}^{\mathrm{o}} \\
\left(\mathrm{MJ} \cdot \mathrm{kg}^{-1}\right)\end{array}$ & $\begin{array}{c}\mathrm{Cp}(\mathrm{T}) \\
\left(\mathrm{kJ} \cdot \mathrm{K}^{-1} \cdot \mathrm{kg}^{-1}\right)\end{array}$ & $\underset{\left(\mathrm{MJ} \cdot \mathrm{kg}^{-1}\right)}{\Delta \mathrm{H}_{\text {ap }}}$ \\
\hline \multicolumn{6}{|l|}{ Char } \\
\hline $51.9 \pm 0.7$ & --- & $5.2 \pm 0.2$ & -1.18 & $\begin{array}{c}0.82\left(25^{\circ} \mathrm{C}\right) \\
1.21\left(300^{\circ} \mathrm{C}\right)\end{array}$ & --- \\
\hline \multicolumn{6}{|c|}{ Non-condensable gas $\left(N_{2}-\right.$ free $)$} \\
\hline $10.1 \pm 0.9$ & $\begin{array}{c}\text { (\%, mass fraction) } \\
\mathrm{CO}_{2}: 74.3 \pm 0.9 \\
\mathrm{CO}: 13.2 \pm 0.1 \\
\mathrm{H}_{2}: 1.7 \pm 0.1 \\
\mathrm{CH}_{4}: 3.8 \pm 0.1 \\
\mathrm{C}_{2} \mathrm{H}_{6}: 1.4 \pm 0.2 \\
\mathrm{C}_{2} \mathrm{H}_{4}: 1.4 \pm 0.1 \\
\mathrm{H}_{2} \mathrm{~S}: 4.3 \pm 0.9\end{array}$ & $8.0 \pm 0.3$ & -7.39 & $\begin{array}{c}1.18\left(25^{\circ} \mathrm{C}\right) \\
1.56\left(530^{\circ} \mathrm{C}\right)\end{array}$ & --- \\
\hline \multicolumn{6}{|c|}{ Light organic phase (LOP) } \\
\hline $2.2 \pm 0.2$ & $\begin{array}{c}\text { Elemental analysis (wt. \%, wet basis) } \\
\text { C:85.9; H:11.8: N:1.8; S:0.2 } \\
100 \text { wt. \% of organic compounds }\end{array}$ & $43.10 \pm 0.04$ & -1.74 & $\begin{array}{c}1.85 \text { (liquid) } \\
3.07\left(530^{\circ} \mathrm{C}\right)\end{array}$ & 0.18 \\
\hline \multicolumn{6}{|c|}{ Heavy organic phase $(\mathrm{HOP})$} \\
\hline $9.4 \pm 0.2$ & $\begin{array}{c}\text { Elemental analysis (wt. \%, wet basis) } \\
\text { C:69.5; H:9.0: N:9.4; S:1.2 } \\
\text { Water: } 6.4 \pm 0.3 \text { wt. } \% \\
\text { Organics: } 93.6 \pm 0.3 \text { wt. } \%\end{array}$ & $32 \pm 2$ & -3.49 & $\begin{array}{l}2.13 \text { (liquid) } \\
2.36\left(530^{\circ} \mathrm{C}\right)\end{array}$ & 0.55 \\
\hline \multicolumn{6}{|c|}{ Aqueous phase (AP) } \\
\hline $20.8 \pm 0.2$ & $\begin{array}{c}\text { Elemental analysis (wt. \%, wet basis) } \\
\text { C:11.2; H:10.5: N:6.5; S:0.4 } \\
\text { Water: } 73.8 \pm 0.4 \text { wt. } \% \\
\text { Organics: } 26.2 \pm 0.4 \text { wt. } \%\end{array}$ & $5.7 \pm 0.3$ & -12.44 & $\begin{array}{l}3.59 \text { (liquid) } \\
2.12\left(530^{\circ} \mathrm{C}\right)\end{array}$ & 1.77 \\
\hline
\end{tabular}

Uncertainty is expressed as mean \pm deviation standard (two replicates were performed). 
Table 3. Experimental results from the gasification of sewage sludge [31].

\begin{tabular}{|c|c|c|c|c|c|c|c|c|c|}
\hline Temperature & 850 & 770 & 850 & 770 & 850 & 770 & 850 & 770 & $810^{*}$ \\
\hline $\mathrm{ER}(\%)$ & 17 & 17 & 12 & 12 & 32 & 32 & 23 & 23 & $19 *$ \\
\hline $\mathrm{O}_{2}$ in enriched-air (vol. \%) & 21 & 21 & 21 & 21 & 33 & 33 & 27 & 27 & $23 *$ \\
\hline S/B (mass ratio) & 0.71 & 0.71 & 0.52 & 0.52 & 0.39 & 0.39 & 0.27 & 0.27 & $0.52 *$ \\
\hline Solid product $\left(\mathrm{g} \cdot \mathrm{kg}^{-1} \mathrm{ss}\right)$ & 368 & 401 & 401 & 407 & 356 & 392 & 384 & 400 & $382 \pm 1$ \\
\hline 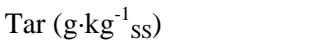 & 25 & 46 & 23 & 49 & 16 & 25 & 14 & 47 & $17 \pm 2$ \\
\hline $\mathrm{H}_{2} \mathrm{O}\left(\mathrm{g} \cdot \mathrm{kg}^{-1} \mathrm{ss}\right)$ & 451 & 515 & 356 & 391 & 352 & 451 & 270 & 336 & $414 \pm 8$ \\
\hline $\mathrm{CO}_{2}\left(\mathrm{~g} \cdot \mathrm{kg}^{-1} \mathrm{ss}\right)$ & 439 & 385 & 304 & 332 & 534 & 524 & 401 & 403 & $418 \pm 4$ \\
\hline $\mathrm{CO}\left(\mathrm{g} \cdot \mathrm{kg}^{-1} \mathrm{ss}\right)$ & 142 & 75 & 156 & 99 & 191 & 97 & 226 & 100 & $138 \pm 1$ \\
\hline $\mathrm{H}_{2}\left(\mathrm{~g} \cdot \mathrm{kg}_{\mathrm{sS}}^{-1}\right)$ & 28.2 & 17.3 & 27.5 & 19.9 & 21.1 & 10.9 & 23.5 & 12.6 & $20.3 \pm 0.2$ \\
\hline $\mathrm{CH}_{4}\left(\mathrm{~g} \cdot \mathrm{kg}^{-1} \mathrm{ss}\right)$ & 29.1 & 26.5 & 31.9 & 32.1 & 24.6 & 22.1 & 26.7 & 25.1 & $27.7 \pm 0.8$ \\
\hline $\mathrm{C}_{2} \mathrm{H}_{6}\left(\mathrm{~g} \cdot \mathrm{kg}^{-1}{ }_{\mathrm{ss}}\right)$ & 4.0 & 4.9 & 3.2 & 4.2 & 2.1 & 1.9 & 2.4 & 4.3 & $2.9 \pm 0.4$ \\
\hline $\mathrm{C}_{2} \mathrm{H}_{4}\left(\mathrm{~g} \cdot \mathrm{kg}^{-1}{ }_{\mathrm{sS}}\right)$ & 22 & 23 & 18 & 25 & 19 & 20 & 19 & 21 & $22 \pm 2$ \\
\hline $\mathrm{C}_{2} \mathrm{H}_{2}\left(\mathrm{~g} \cdot \mathrm{kg}^{-1}{ }_{\mathrm{sS}}\right)$ & 0.9 & 0.9 & 0.4 & 0.9 & 1.1 & 1.1 & 1.0 & 1.0 & $1.0 \pm 0.1$ \\
\hline $\mathrm{H}_{2} \mathrm{~S}\left(\mathrm{~g} \cdot \mathrm{kg}_{\mathrm{sS}}^{-1}\right)$ & 8.7 & 6.1 & 6.2 & 5.5 & 8.8 & 7.1 & 7.4 & 4.9 & $7.1 \pm 0.4$ \\
\hline $\mathrm{N}_{2}\left(\mathrm{~g} \cdot \mathrm{kg}^{-1} \mathrm{ss}\right)$ & 734 & 677 & 533 & 502 & 742 & 747 & 711 & 690 & $703 \pm 6$ \\
\hline$\eta_{\text {gas }}\left(\mathrm{m}_{\mathrm{STP}}^{3} \cdot \mathrm{kg}_{\mathrm{SS}}^{-1}\right)$ & 1.31 & 1.06 & 1.23 & 1.09 & 1.31 & 1.12 & 1.28 & 1.04 & $1.18 \pm 0.01$ \\
\hline $\mathrm{LHV}_{\mathrm{gas}}\left(\mathrm{MJ} \cdot \mathrm{m}_{\mathrm{STP}}^{3}\right)$ & 5.9 & 5.3 & 7.1 & 6.9 & 5.2 & 4.1 & 6.0 & 4.9 & $5.6 \pm 0.1$ \\
\hline
\end{tabular}

* Three replicates were performed at the center point of the experimental design. Mean \pm standard deviation of these replicates is shown. 
Table 4. Experimental results from the gasification of char [32].

\begin{tabular}{|c|c|c|c|c|c|c|c|c|c|}
\hline Temperature & 850 & 770 & 850 & 770 & 850 & 770 & 850 & 770 & $810^{*}$ \\
\hline $\mathrm{ER}(\%)$ & 17 & 17 & 12 & 12 & 32 & 32 & 23 & 23 & $19 *$ \\
\hline $\mathrm{O}_{2}$ in enriched-air (vol. \%) & 27 & 27 & 21 & 21 & 40 & 40 & 33 & 33 & $29 *$ \\
\hline S/B (mass ratio) & 0.71 & 0.71 & 0.52 & 0.52 & 0.39 & 0.39 & 0.27 & 0.27 & $0.52 *$ \\
\hline Solid product $\left(\mathrm{g} \cdot \mathrm{kg}^{-1}\right.$ char $)$ & 757 & 785 & 750 & 785 & 731 & 771 & 752 & 813 & $775 \pm 2$ \\
\hline $\operatorname{Tar}\left(\mathrm{g} \cdot \mathrm{kg}^{-1}{ }_{\text {char }}\right)$ & 2 & 12 & 2 & 5 & 2 & 9 & 5 & 7 & $5 \pm 1$ \\
\hline $\mathrm{H}_{2} \mathrm{O}\left(\mathrm{g} \cdot \mathrm{kg}^{-1}\right.$ char $)$ & 119 & 160 & 78 & 99 & 88 & 99 & 59 & 69 & $112 \pm 11$ \\
\hline $\mathrm{CO}_{2}\left(\mathrm{~g} \cdot \mathrm{kg}^{-1}{ }_{\text {char }}\right)$ & 195 & 206 & 154 & 164 & 232 & 254 & 177 & 190 & $198 \pm 5$ \\
\hline $\mathrm{CO}\left(\mathrm{g} \cdot \mathrm{kg}^{-1}{ }_{\text {char }}\right)$ & 128 & 65 & 122 & 64 & 148 & 77 & 144 & 76 & $91 \pm 3$ \\
\hline $\mathrm{H}_{2}\left(\mathrm{~g} \cdot \mathrm{kg}^{-1}{ }_{\text {char }}\right)$ & 13.7 & 10.1 & 12.0 & 8.9 & 10.0 & 7.4 & 9.6 & 7.2 & $10.3 \pm 0.1$ \\
\hline $\mathrm{CH}_{4}\left(\mathrm{~g} \cdot \mathrm{kg}^{-1}\right.$ char $)$ & 2.8 & 2.8 & 2.6 & 2.6 & 2.2 & 2.2 & 2.2 & 2.4 & $2.9 \pm 0.1$ \\
\hline $\mathrm{C}_{2} \mathrm{H}_{4}\left(\mathrm{~g} \cdot \mathrm{kg}^{-1}{ }_{\text {char }}\right)$ & 0.07 & 0.07 & 0.06 & 0.08 & 0.06 & 0.08 & 0.05 & 0.07 & $0.07 \pm 0.01$ \\
\hline $\mathrm{H}_{2} \mathrm{~S}\left(\mathrm{~g} \cdot \mathrm{kg}^{-1}\right.$ char $)$ & 1.97 & 0.76 & 0.99 & 0.44 & 1.38 & 0.56 & 0.90 & 0.36 & $0.68 \pm 0.03$ \\
\hline $\mathrm{N}_{2}\left(\mathrm{~g} \cdot \mathrm{kg}^{-1}\right.$ char $)$ & 205 & 197 & 211 & 204 & 212 & 201 & 213 & 198 & $207 \pm 8$ \\
\hline$\eta_{\text {gas }}\left(\mathrm{m}_{\text {STP }}^{3} \cdot \mathrm{kg}^{-1}\right.$ char $)$ & 0.52 & 0.43 & 0.48 & 0.40 & 0.52 & 0.44 & 0.49 & 0.40 & $0.46 \pm 0.01$ \\
\hline $\mathrm{LHV}_{\mathrm{gas}}\left(\mathrm{MJ} \cdot \mathrm{m}_{\mathrm{STP}}^{3}\right)$ & 6.0 & 4.7 & 5.9 & 4.7 & 5.4 & 4.1 & 5.6 & 4.4 & $5.1 \pm 0.1$ \\
\hline
\end{tabular}

* Three replicates were performed at the center point of the experimental design. Mean \pm standard deviation of these replicates is shown. 
Table 5. Energy recovery from the product gas and efficiency of sewage sludge gasification and char gasification according to experimental and equilibrium data.

\begin{tabular}{lccccccccc}
\hline Temperature & 850 & 770 & 850 & 770 & 850 & 770 & 850 & 770 & 810 \\
ER (\%) & 17 & 17 & 12 & 12 & 32 & 32 & 23 & 23 & 19 \\
S/B (mass ratio) & 0.71 & 0.71 & 0.52 & 0.52 & 0.39 & 0.39 & 0.27 & 0.27 & 0.52 \\
\hline
\end{tabular}

Sewage sludge gasification (experimental results)

Energy in gas ( $\left.\mathrm{MJ} \cdot \mathrm{kg}^{-1} \mathrm{ss}\right)$ $10.23 \quad 7.91$

9.63

8.419 .10

6.77

9.56

6.93

$8.72 \pm 0.12$

Gasification efficiency (\%)

$74 \quad 58$

65

Sewage sludge gasification (equilibrium results)

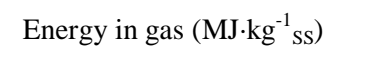

14.37

14.11

14.95

61

87

75

82

65

$71 \pm 2$

Gasification efficiency (\%)

$90 \quad 91$

Char gasification (experimental results)

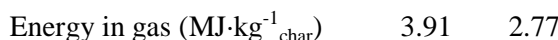

Gasification efficiency (\%)

51

32

$\begin{array}{cc}3.49 & 2.44 \\ 40 & 23\end{array}$

3.52

2.44

3.34

2.27
33

$2.98 \pm 0.05$

Char gasification (equilibrium results)

\begin{tabular}{lccccccccc} 
Energy in gas $\left(\mathrm{MJ}^{-\mathrm{kg}^{-1} \text { char }}\right)$ & 6.19 & 6.09 & 6.53 & 6.42 & 4.94 & 4.85 & 5.62 & 5.53 & 5.95 \\
Gasification efficiency $(\%)$ & 75 & 80 & 80 & 81 & 82 & 83 & 82 & 84 & 81 \\
\hline
\end{tabular}


(i) Air-steam gasification of sewage sludge

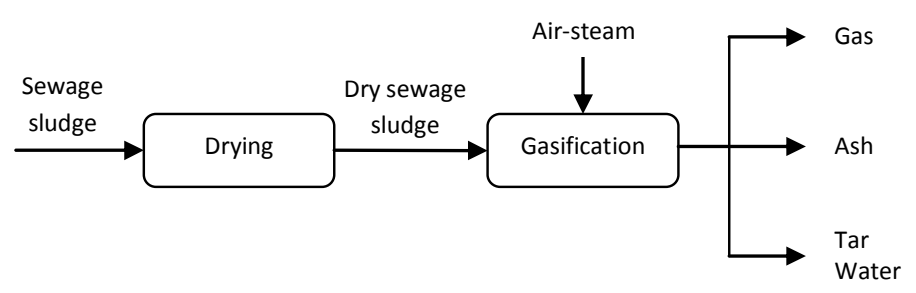

(ii) Pyrolysis of sewage sludge + air-steam gasification of char

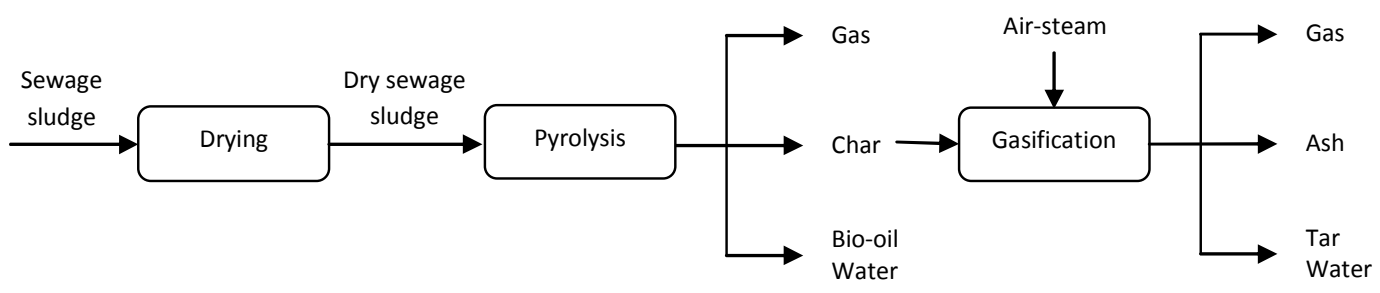

Fig.1. Overview scheme of the thermo-chemical processes proposed for sewage sludge treatment. 


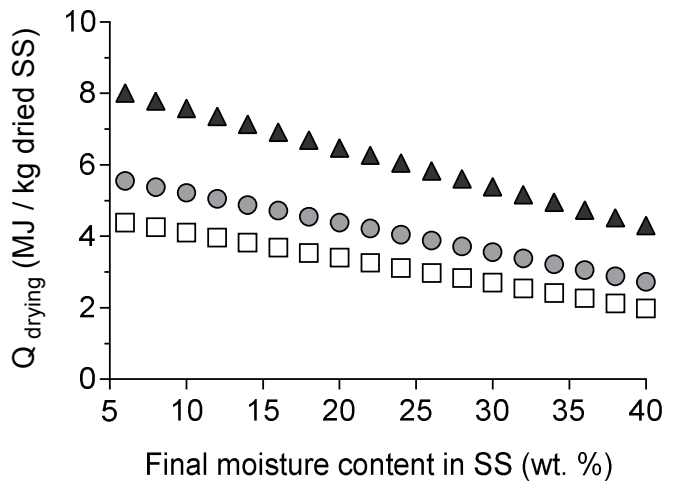

Initial moisture content: $\quad \Delta \quad 77$ wt. $\% \quad$ ○ 70 wt. $\% \quad \square \quad 65$ wt. $\%$

Fig. 2. Heat demand for the thermal drying of sewage sludge (SS) as a function of the initial and final moisture contents. 
(a) SS gasification (experimental data)

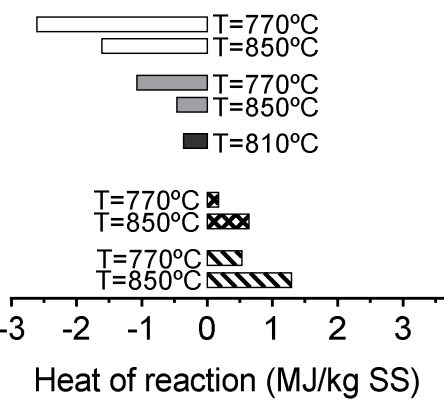

(c) SS gasification (equilibrium data)

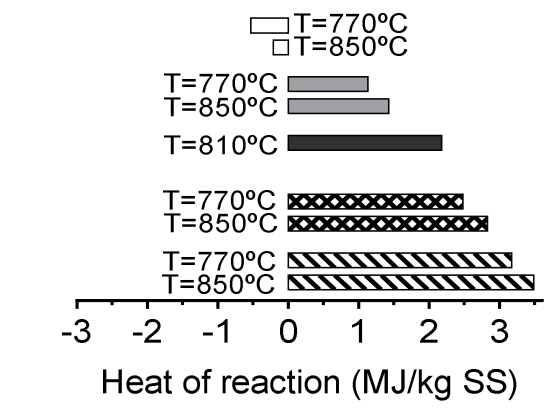

$\square \begin{aligned} & E R=32 \% \\ & S / B=0.39\end{aligned} \square \begin{aligned} & E R=23 \% \\ & S / B=0.27\end{aligned} \square \begin{aligned} & E R=19 \% \\ & S / B=0.52\end{aligned}$ (b) Char gasification (experimental data)

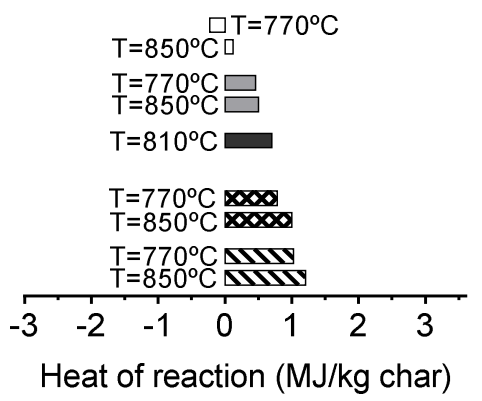

(d) Char gasification (equilibrium data)

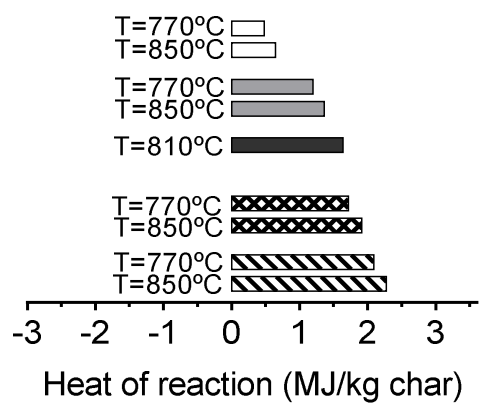

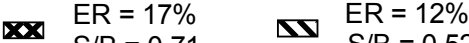
$S / B=0.71 \quad \triangle \quad S / B=0.52$

Fig. 3. Heats of reaction for sewage sludge (SS) gasification (a, c) and char gasification (b, d) based on both experimental and equilibrium data. 
(a)

$$
\text { SS gasification; } \mathrm{T}=800^{\circ} \mathrm{C}
$$

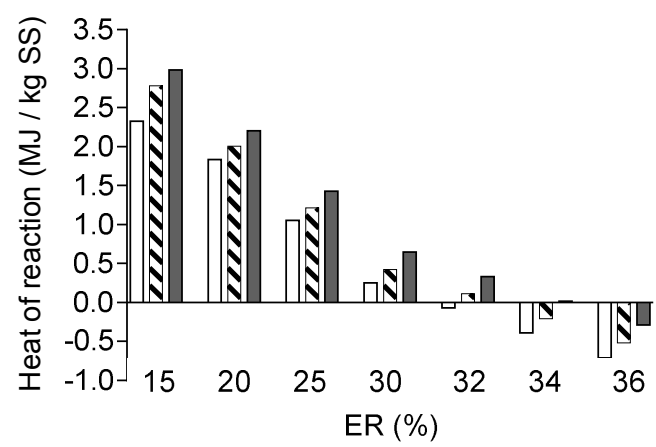

(c)

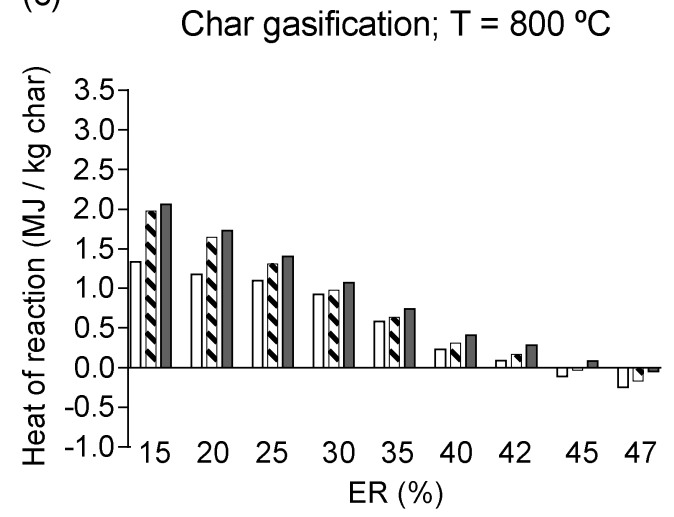

$\square \mathrm{S} / \mathrm{C}=0 \quad \mathbf{\mathrm { N }} \mathrm{S} / \mathrm{C}=0.5 \square \mathrm{S} / \mathrm{C}=1$ (b)

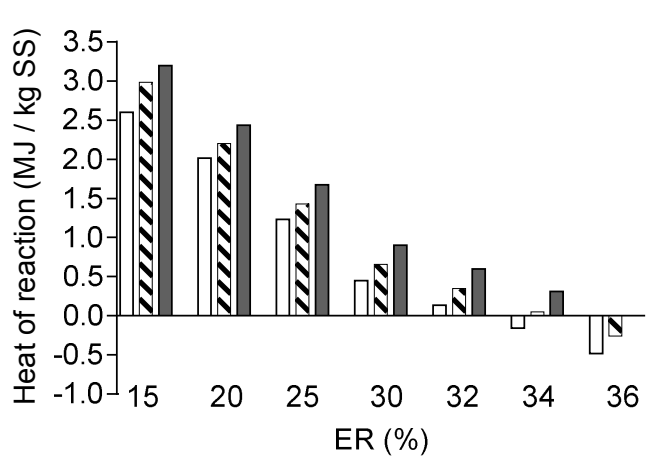

(d)

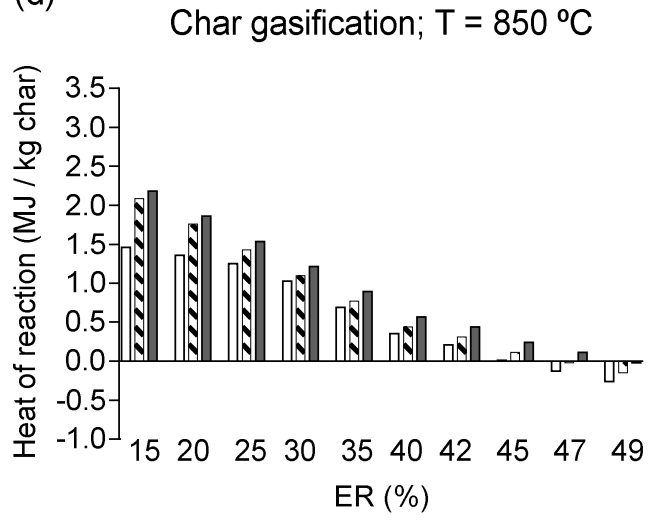

Fig. 4. Heats of reaction for sewage sludge (SS) gasification (a, b) and char gasification (c, d) at $800{ }^{\circ} \mathrm{C}$ and $850{ }^{\circ} \mathrm{C}$ according to equilibrium data. 
(a)

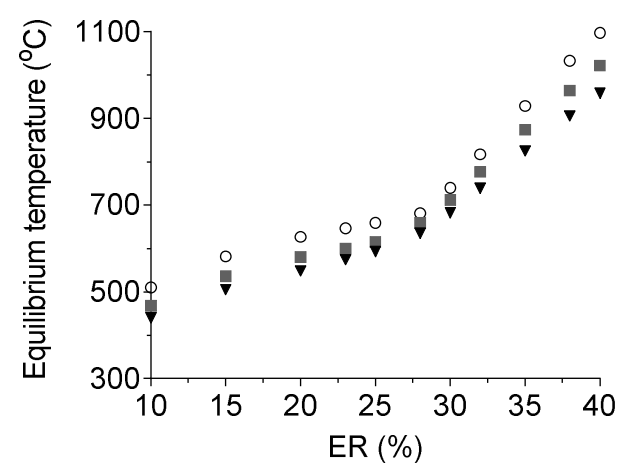

(b)

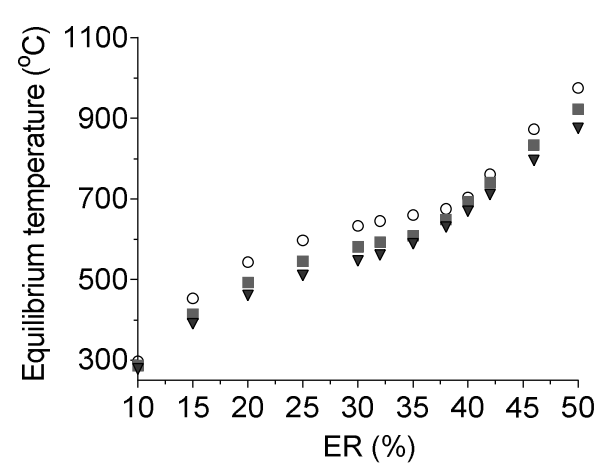

$\mathrm{S} / \mathrm{C}=0 \quad \mathrm{~S} / \mathrm{C}=0.5 \quad \nabla \mathrm{S} / \mathrm{C}=1$

Fig. 5. Equilibrium temperature as a function of the equivalence ratio (ER) and the steam to carbon molar ratio (S/C) during sewage sludge (SS) gasification and char gasification. 
(a) Two-stage process (SS drying + SS gasification)

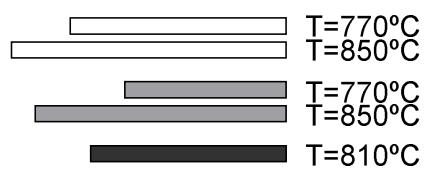

$\begin{array}{rl}x \times x \times x \times x & T=770^{\circ} \mathrm{C}\end{array}$

IIIIIIII $\mathrm{T}=770^{\circ} \mathrm{C}$

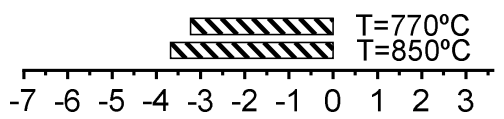

Total energy demand (MJ/kg SS) (b) Three-stage process (SS drying+SS pyrolysis+char gasification)

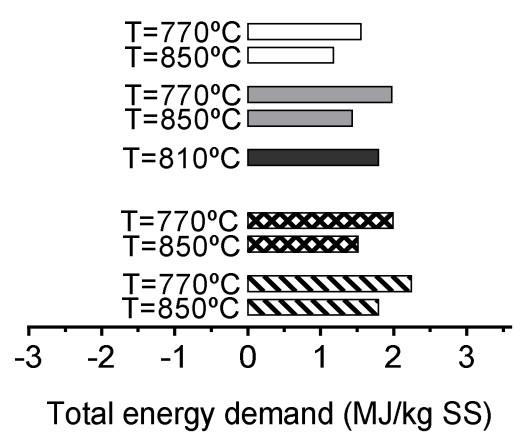

$\square \begin{aligned} & E R=32 \% \\ & S / B=0.39\end{aligned} \square \begin{aligned} & E R=23 \% \\ & S / B=0.27\end{aligned} \square \begin{aligned} & E R=19 \% \\ & S / B=0.52\end{aligned} \quad \times \begin{aligned} & E R=17 \% \\ & S / B=0.71\end{aligned} \quad \mathbf{D} \begin{aligned} & E R=12 \% \\ & S / B=0.52\end{aligned}$

Fig. 6. Total energy demand for the two-stage and three-stage processes for sewage sludge (SS) treatment (experimental data). 